\title{
ASOSIASI KETERJADIAN KOLONI VERTICILLIUM DAN INTENSITAS NAUNGAN SERTA LETAK DAUN KOPI
}

\author{
Subli Mujim¹, Rudi Ruswandi², Cipta Ginting¹, dan Rusdi Evizal ${ }^{3}$
}

\begin{abstract}
Association of Verticillium colony intensity and shade and coffee leaf position. Since conventional control methods of leaf rust of coffee is still unsatisfactory, it is needed to study toward the possibility of using biocontrol agents including factors that may influence the occurrence of the agents. The objective of this study was to determine the strength of the association of Verticillium colony occurrence and shade and leaf position. Leaf samples were taken from four sites at three coffee fields at Sumberjaya Sub district, West Lampung. Samples were taken from plants with and without shade. From each shade level, leaves showing symptoms were taken from the plants and from the ground (fallen leaves). The samples were placed individually on plastic bag and transported to the laboratory, where the samples were incubated for four days at room temperature. The proportion of lesion caused by $H$. vastatrix on coffee leaves that showed whitish Verticillium colonies was recorded and modified to score 0 (without Verticillium colony) to 4 (colony $50 \%$ or more). Data were analyzed with log linear saturated model. Data suggested that the occurrence of Verticillium colony was higher on plant with canopy compared to that on plants without canopy. In addition, Verticillium occurred more frequently on leaves still on the plants compared to that on leaves on the ground. Canopy factor was relatively stronger than leaf position factor in influencing the occurrence of Verticillium colony.
\end{abstract}

Key words: leaf rust of coffee, Hemileia vastatrix, micoparasitism, Verticillium

\section{PENDAHULUAN}

Salah satu masalah utama dalam budidaya tanaman kopi (Coffee spp.) terutama jenis arabika (C. arabica L.) ialah penyakit karat daun yang disebabkan oleh Hemileia vastatrix B. et $\mathrm{Br}$. Kerusakan pada tanaman terjadi akibat daun yang terserang berat akan gugur dan akhirnya menyebabkan kematian tanaman (Semangun, 2000). Karena cara pengendalian yang konvensional seperti aplikasi fungisida hasilnya kurang memuaskan, perlu diadakan penelitian ke arah penggunaan agensia hayati untuk mengendalikan penyakit tersebut.

Salah satu jamur yang sudah diketahui dapat hidup sebagai hiperparasit adalah Verticillium (Benhamou and Brodeur, 2000; Heale, 2000) dan telah dilaporkan terdapat pada daun kopi dengan gejala panyakit karat (Askary et al., 1997; Mawardi, 1996; Yun et al. 1991). Mawardi (1996) melaporkan bahwa $V$. lecanii memarasiti jamur $H$. vastatrix secara alami. Hiperparasitisme itu tampak secara makroskopis berupa miselium putih pada bilur daun kopi seperti disebutkan di atas. Lebih daripada itu, pada inokulasi buatan di laboratorium dengan menggunakan cakram daun pun diperlukan upaya khusus untuk menghindari infeksi $V$. lecanii terhadap patogen, yaitu dengan melakukan sterilisasi pada permukaan daun yang telah menunjukkan gejala awal penyakit karat. Askary et al., (1997) melaporkan bahwa Verticillium mempunyai kisaran inang yang luas termasuk Uromyces dianthi pada carnation, $U$. appendiculatus pada dwarf bean, Puccinia recondita pada gandum, Oidium tingtanium pada jeruk, Erysiphe graminis pada barlei, dan S. fuliginea pada ketimun.

Campbell (1989) menjelaskan bahwa mikoparasitisme ini sebenarnya sudah terjadi secara alami. Namun, karena pengaruh lingkungan yang diciptakan penanam sendiri dalam kegiatan budidaya kopi yang menguntungkan $H$. vastatrix, musuh alami tidak saja kurang didukung, tetapi malah dirugikan dengan praktik budidaya khususnya aplikasi fungisida. Sebagai contoh Mulinge dan Griffits melaporkan bahwa tanaman kopi yang disemprot tembaga, kaptafol, atau benomil pada tahun 1969 saja menurunkan penyakit pada tahun itu. Akan tetapi, jika tidak disemprot pada tahun berikutnya, tanaman itu terserang lebih berat jika dibandingkan dengan tanaman yang tidak disemprot pada 1969 itu. Tanaman yang disemprot pada tahun 1969 harus disemprot lagi pada tahun 1970 agar penyakit karat daun kopi (KDK) tetap terkendali. Hal ini menunjukkan dua hal: (1) terjadi penekanan penyakit oleh antagonis secara alami dan (2) penyemprotan

\footnotetext{
${ }^{1}$ Dosen Jurusan Proteksi Tanaman, Fakultas Pertanian Universitas Lampung

${ }^{2}$ Dosen Jurusan Matematika FMIPA Universitas Lampung

${ }^{3}$ Dosen Jurusan Budidaya Pertanian, Fakultas Pertanian Universitas Lampung
} 
tanaman dengan fungsida menekan patogen maupun antagonisnya sehingga pada tahun berikutnya patogen berkembang tanpa hambatan oleh antagonis.

Salah satu aspek yang perlu dipelajari ialah faktor yang mungkin mempengaruhi keterjadian Verticillium pada bilur karat daun kopi. Kopi biasanya tumbuh di bawah naungan yang berupa tajuk suatu pohon. Di samping itu, pada tanaman kopi yang terserang $H$. vastatrix daun dapat gugur lebih dini daripada yang terjadi pada tanaman sehat. Penelitan ini bertujuan untuk mengetahui tingkat asosiasi keterjadian koloni Verticillium dan aras naungan dan letak daun (belum gugur atau sudah gugur).

\section{METODE PENELITIAN}

Pengamatan dilakukan di empat situs (A, B, C, dan D) di tiga kebun kopi di Kecamatan Sumberjaya Kabupaten Lampung Barat. Terlebih dulu ditentukan dua faktor pada kebun masing-masing dengan dua aras, yaitu kebun naungan (dan atau tidak ada naungan) dan posisi daun (belum gugur atau sudah gugur). Dari setiap situs tersebut diambil terok berupa delapan daun kopi yang menunjukkan gejala penyakit karat. Pengambilan terok dilakukan dengan terlebih dulu menentukan satu ranting pada setiap arah angin (utara, selatan, timur, dan barat) pada bagian tengah tajuk tanaman kopi sehingga diperoleh empat ranting. Pada bagian pangkal masing-masing ranting diambil dua daun sehingga diperoleh delapan daun dari setiap tanaman kopi. Kemudian setiap helai daun diletakan dalam satu kantung plastik agar tidak terjadi kontaminasi antar-daun. Di laboratorium, semua terok diinkubasikan selama 4 hari.

Setiap daun diamati untuk menentukan persentase bilur yang mengandung Verticillium. Data yang diolah ialah data hasil pengamatan pada hari kedua, yang hampir sama dengan data hasil pengamatan hari ketiga dan keempat. Peubah yang diamati ialah proporsi bilur pada masing-masing daun yang ditumbuhi Verticillium yang dicirikan oleh koloni jamur berwarna putih. Proporsi tersebut dicatat dan diubah ke skor. Skor yang digunakan ialah 0-4 dengan 0 berarti tanpa koloni Verticillium pada bilur dan 4 berarti $50 \%$ bilur pada daun atau lebih ditumbuhi koloni Verticillium. Data yang diperoleh dianalisis dengan menggunakan model log linear lengkap (saturated model) dengan menggunakan SPSS 11.5 .

\section{HASIL DAN PEMBAHASAN}

Analisis data didahului dengan mengajukan perumusan hipotesis bahwa apakah terdapat interaksi yang signifikan antara faktor naungan, posisi daun, dan skor untuk banyaknya koloni Verticillium, maka model matematik untuk permasalahan tersebut dapat diungkapkan ke dalam model log linear lengkap (saturated model) sebagai berikut,

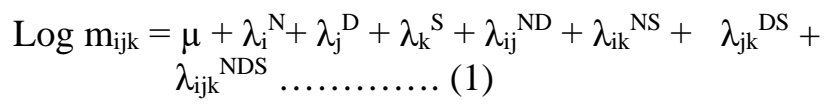

dengan:

$\log m_{\mathrm{ijk}}=\log$ nilai harapan (expected values) untuk setiap sel

$\mu \quad=$ rataan umum

$\lambda_{\mathrm{i}}^{\mathrm{N}} \quad=$ pengaruh utama ke-i dari faktor naungan

$\lambda_{j}^{\mathrm{D}} \quad=$ pengaruh utama ke-j dari faktor daun

$\lambda_{\mathrm{k}} \mathrm{S} \quad=$ pengaruh utama ke-k dari faktor skor

$\lambda_{\mathrm{ij}}^{\mathrm{ND}} \quad=$ pengaruh interaksi ke-i dan ke-j dari faktor naungan dan daun

$\lambda_{\mathrm{ik}}{ }^{\mathrm{NS}}=$ pengaruh interaksi ke-i dan ke-k dari faktor naungan dan skor

$\lambda_{\mathrm{jk}}^{\mathrm{DS}}=$ pengaruh interaksi ke-j dan ke-k dari faktor daun dan skor

$\lambda_{\mathrm{ijk}}{ }^{\mathrm{NDS}}=$ pengaruh interaksi ke-i, ke-j, dan ke-k dari faktor naungan, daun, dan skor.

Perumusan hipotesis untuk interaksi tiga faktor dinyatakan sebagai berikut:

Ho $: \lambda_{\mathrm{ijk}}{ }^{\mathrm{NDS}}=0$ versus

H1 : tidak semua $\lambda_{\mathrm{ijk}}{ }^{\mathrm{NDS}}=0$.

Hasil analisis untuk model di atas dengan menggunakan software SPSS 11.5 ditunjukkan pada Tabel 1.

Tabel 1. Hierarchical log linear

\begin{tabular}{llll}
\hline K & DF & LR Chisqr. & Prob. \\
\hline 1 & 6 & 58,673 & 0,0000 \\
2 & 9 & 32,232 & 0,0002 \\
3 & 4 & 4,711 & 0,3182 \\
\hline
\end{tabular}

Tabel di atas menyatakan bahwa untuk K (yang menyatakan banyaknya faktor) $=3$, diperoleh nilai prob. $=0,3182$ (yang lebih besar dari $5 \%$ ) yang berarti hipotesis untuk interaksi tiga faktor yaitu Ho : $\lambda_{\mathrm{ijk}}{ }^{\mathrm{NDS}}$ $=0$ tidak ditolak, atau tidak ada satupun interaksi tiga faktor dengan semua arasnya signifikan. 
Selanjutnya, dilihat model log linear yang melibatkan dua faktor, dari tabel hasil analisis di atas untuk $\mathrm{K}=2$, diperoleh nilai prob. $=0,0002$ (lebih kecil dari $5 \%$ sehingga data mendukung untuk menolak perumusan hipotesis Ho: $\lambda_{\mathrm{ij}}{ }^{\mathrm{ND}}=\lambda_{\mathrm{ik}}{ }^{\mathrm{NS}}=\lambda_{\mathrm{jk}} \mathrm{DS}$ $=0$, atau terdapat paling tidak sebuah interaksi dua faktor yang signifikan. Untuk melihat faktor yang saling berinteraksi secara signifikan dilakukan pengujian asosiasi secara parsial yang hasilnya seperti terlihat pada Tabel 2.

Dari tabel prob dapat dilihat bahwa untuk interaksi antara letak daun dan skor serta interaksi antara naungan dan skor, masing-masing bernilai 0,0198 dan 0,0004 yang lebih kecil dari 5\%. Hal ini berarti bahwa kedua interaksi tersebut layak untuk dimasukkan ke dalam model log linear, sedangkan untuk interaksi faktor letak daun dan naungan nilai prob-nya lebih besar dari 5\% sehingga interaksi kedua faktor tersebut tidak dimasukkan ke dalam model. Selain itu juga dapat dilihat bahwa untuk faktor utama skor nilai prob-nya $=0,0000$. Hal ini dapat ditafsirkan bahwa dari ketiga faktor utama hanya faktor skor saja yang memberikan level skor koloni Verticillium yang saling berbeda secara signifikan, sedangkan faktor letak daun (tidak gugur versus gugur) tidak memberikan perbedaan yang berarti. Sama halnya dengan faktor naungan (naungan banyak versus naungan sedikit) tidak memberikan perbedaan yang berarti. Berdasarkan uraian di atas maka untuk menduga nilai-nilai harapan (expected values) masing-masing sel pengamatan, model log-linear yang dianggap paling sesuai adalah:

$$
\log m_{i j k}=\mu+\lambda_{k}{ }^{S}+\lambda_{i k}{ }^{N S}+\lambda_{j k}{ }^{D S}
$$

Dengan demikian, secara kuantitatif (berdasarkan data), hubungan antar - peubah tersebut dapat digambarkan sebagai berikut:

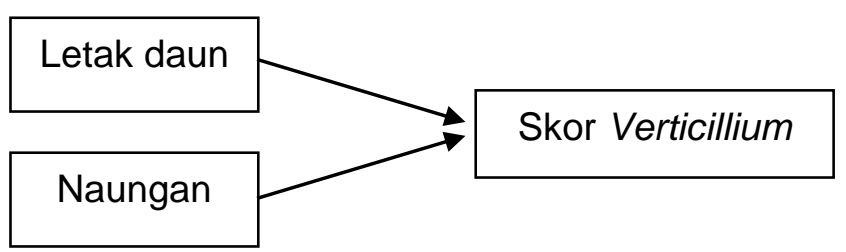

Gambar 1. Hubungan antar-peubah. Tidak terdapat asosiasi antara Posisi Daun dan Naungan.

Pada bagian akhir dari analisis statistik atas data asosiasi keterjadian koloni Verticillium dan kedua faktor, diterakan nilai harapan (expected values) seperti dapat dilihat pada Tabel 3.

Tabel 3 menunjukkan bahwa faktor naungan relatif lebih penting jika dibandingkan dengan faktor posisi daun dalam menentukan persentase koloni Verticillium pada daun kopi. Hal ini tampak pada relatif lebih besarnya nilai expected count pada koloni Verticillium 'tampak' (<10\% sampai > 50\%) dengan naungan banyak jika dibandingkan dengan yang terdapat pada naungan sedikit. Hal sebaliknya terjadi pada kolom koloni Verticillium 'tidak tampak'. Perbedaan angka pada posisi daun tidak gugur versus gugur tidak sebesar yang terjadi pada naungan banyak versus naungan sedikit.

Bahwa faktor naungan relatif lebih menentukan tampak pula jika digunakan rasio kecenderungan (statistic ratio odd), yaitu ukuran

Tabel 2. Uji asosiasi parsial

\begin{tabular}{lcccc}
\hline Effect Name & DF & Partial Chisq & Prob & Iter \\
\hline Daun*Naungan & 1 & 0,001 & 0,9743 & 2 \\
Daun*Skor & 4 & 11,689 & 0,0198 & 2 \\
Naungan*Skor & 4 & 20,543 & 0,0004 & 2 \\
Daun & 1 & 0,000 & 1,0000 & 2 \\
Naungan & 1 & 0,000 & 1,0000 & 2 \\
Skor & 4 & 58,673 & 0,0000 & 1 \\
\hline
\end{tabular}

Tabel 3. Nilai expected values untuk model (2)

\begin{tabular}{clccccc}
\hline \multirow{2}{*}{$\begin{array}{c}\text { Letak } \\
\text { Daun }\end{array}$} & Naungan & \multicolumn{5}{c}{ Expected Count untuk Persentase Koloni Verticillium } \\
\cline { 3 - 6 } & & Tidak Tampak & $<10 \%$ & $(10-25) \%$ & $(25-50) \%$ & $>50 \%$ \\
\hline Tidak & Banyak & 0,2 & 1,3 & 6,7 & 10,7 & 13,0 \\
gugur & Sedikit & 2,8 & 0,7 & 13,3 & 9,3 & 6,0 \\
Gugur & Banyak & 0,8 & 0,7 & 2,3 & 11,3 & 17,0 \\
& Sedikit & 9,2 & 0,3 & 4,7 & 9,7 & 8,0 \\
\hline
\end{tabular}


statistik yang menyatakan asosiasi atau kecenderungan dari aras faktor baris terhadap aras faktor kolom. Misalnya, untuk posisi daun tidak gugur, persentase koloni Verticillium yang tampak (keseluruhan skor tampak) pada naungan banyak diperoleh 15,147 kali daripada yang terdapat pada naungan sedikit dengan perhitungan berikut:

$$
\frac{(1,3+6,7+10,7+13,0) / 0,2}{(0,7+13,3+9,3+6,0) / 2,8}=15,147 .
$$

Untuk posisi daun gugur, persentase koloni Verticillium yang tampak (keseluruhan skor tampak) pada naungan banyak diperoleh 15,857 kali daripada yang terdapat pada naungan sedikit dengan perhitungan berikut:

$$
\frac{(0,7+2,3+11,3+17,0) / 0,8}{(0,3+4,7+9,7+8,0) / 9,2}=15,857 \text {. }
$$

Jika rasio kecenderungan tersebut digunakan dengan menghitung angka yang serupa untuk membandingkan expected count pada daun tidak gugur versus daun gugur, maka diperoleh angka yang relatif lebih kecil daripada yang di atas. Untuk naungan banyak, persentase koloni Verticillium yang tampak (keseluruhan skor tampak) pada daun tidak gugur diperoleh 4,051 kali daripada yang terdapat pada daun gugur dengan perhitungan berikut:

$$
\begin{aligned}
& (1,3+6,7+10,7+13,0) / 0,2 \\
& -(0,7+2,3+11,3+17,0) / 0,8
\end{aligned}=4,051 .
$$

Untuk naungan sedikit, persentase koloni Verticillium yang tampak (keseluruhan skor tampak) pada daun tidak gugur diperoleh 4,242 kali daripada yang terdapat pada daun gugur dengan perhitungan berikut:

$$
\frac{(0,7+13,3+9,3+6,0) / 2,8}{-(0,3+4,7+9,7+8,0) / 9,2}
$$

Data hasil pengamatan keterjadian koloni Verticillium pada daun kopi menunjukkan bahwa frekuensi keterjadian koloni tersebut relatif tinggi. Koloni Verticillium masih tampak pada bilur karat pada daun kopi meskipun daun tersebut telah gugur. Koloni Verticillium relatif lebih sering ditemukan pada daun tidak gugur daripada yang terjadi pada daun gugur. Meskipun demikian, faktor naungan lebih menentukan keberadaan koloni Verticillium daripada faktor posisi daun. Perlu dicatat bahwa pada percobaan ini tidak dinilai keparahan penyakit karat daun kopi sehingga tidak dapat dianalisis apakah keberadaan koloni Verticillium ditentukan oleh intensitas penyakit. Dapat disarankan untuk mengukur keparahan penyakit sehingga dapat diketahui apakah intensitas penyakit yang lebih tinggi menyebabkan lebih banyak koloni Verticillium.

Data hasil pengamatan ini menunjukkan bahwa potensi antagonis secara logis dapat diharapkan tetap ada untuk mengurangi potensi inokulum $H$. vastatrix meskipun daun telah gugur. Telah diketahui bahwa antagonis tersebut bersifat parasit fakultatif, yaitu dapat hidup dari uredospora dan uredium pathogen dan dari bahan-bahan organik yang telah mati (Heale, 2000).

Tingkat naungan dan letak daun diteliti secara khusus karena kedua faktor ini diduga sangat relevan. Kopi biasanya dinaungi oleh suatu pohon pelindung. Naungan mempengaruhi kondisi kebun kopi terutama kelembaban nisbi. Kelembaban nisbi sangat mempengaruhi jamur seperti Verticillium dan $H$. vastatrix. Kelembaban mempengaruhi perkecambahan spora, pertumbuhan, dan penyebaran jamur (Agrios, 1997). Faktor kedua ialah letak daun, apakah daun masih pada ranting atau telah gugur. Daun yang terserang biasanya gugur sebelum waktunya. Dengan demikian, akan lebih banyak daun gugur pada pertanaman jika intensitas penyakit karat tinggi dibandingkan dengan yang terjadi jika intensitas penyakit rendah (Semangun, 2000). Letak daun diduga berkaitan dengan multifaktor yang menentukan potensi inokulum agensia hayati.

Data yang diperoleh dari penelitian ini dan informasi yang telah dipublikasikan sebelumnya seperti yang dikutip pada tulisan ini mengindikasikan adanya potensi Verticillium yang berasosiasi dengan $H$. vastatrix sebagai agen pengendali hayati penyakit karat daun kopi. Verticillium relatif lebih sering terdapat pada pertanaman kopi dengan naungan yang banyak jika dibandingkan dengan yang terjadi pada naungan yang sedikit. Frekuensi keterjadian koloni Verticillium pada daun yang belum gugur relatif lebih tinggi jika dibandingkan dengan yang terjadi pada daun gugur. 


\section{SANWACANA}

Penelitian ini merupakan sebagian dari penelitian yang dilakukan dengan dukungan dana dari Proyek RUT XI. Penulis menyampaikan terima kasih kepada Pengelola Proyek RUT XI dan Pimpinan Lembaga Penelitian Unila sehingga penelitian sejauh ini dapat berlangsung. Penulis juga menyampaikan terima kasih kepada Yusuf, Farida Ariani, S.P., Tri Maryono, S.P., Paryadi yang telah membantu kami di laboratorium dan di lapangan.

\section{DAFTAR PUSTAKA}

Agrios, G.N. 1997. Plant Pathology. $4^{\text {th }}$ ed. Academic Press, San Diago.

Askary, H., N. Benhamou, and J. Brodeur. 1997. Ultrastructural and cytochemical investigations of the antagonistic effect of Verticillium lecanii on cucumber powdery mildew. Phytopathology 87: 359-368.

Benhamou, N. and J. Brodeur. 2000. Evidence for antibiosis and induced host reactions in the interaction between Verticillium lecanii and Penicillium digitatum, the causal agent of green mold. Phytopathology 90:932-943.
Campbell, R. 1989. Biological Control of Microbial Plant Pathogens. Cambridge Univ. Press, Cambridge.

Heale, J.B. 2000. Diversification and speciation in Verticillium - an overview. Pages 1- 14 in: Tjamos, E.C., R.C. Rowe, J.B. Heale, and D.R. Fravel. Eds. Advances in Verticillium: Research and disease management. APS Press, St. Paul, Minnesota.

Mawardi, S. 1996. Kajian Genetika Ketahanan Tak Lengkap Kopi Arabika terhadap Penyakit Karat Daun (Hemileia vastatrix B. et Br.) di Indonesia. Disertasi. Universitas Gadjah Mada, Yogyakarta.

Semangun, H. 2000. Penyakit-penyakit Tanaman Perkebunan di Indonesia. Edisi kedua. Gadjah Mada University Press, Yogyakarta.

Yun, Y., P.D. Bridge, and H.C. Evans. 1991. An integrated approach to the taxonomy of the genus Verticillium. J. Gen. Microbiol. 137:1437-1444. 
